\title{
Editorial
}

\section{Welcome to Seminars in Thrombosis \& Hemostasis 2021-New (2019) Impact Factor and Most Highly Cited Papers}

\author{
Emmanuel J. Favaloro, PhD, FFSc (RCPA) ${ }^{1}$ \\ 1 Department of Haematology, Centres for Thrombosis and \\ Haemostasis, Institute of Clinical Pathology and Medical Research \\ (ICPMR), Westmead Hospital, Westmead, New South Wales, \\ Australia
}

Semin Thromb Hemost 2021;47:1-5.

Welcome to the start of another year with Seminars in Thrombosis \& Hemostasis (STH), this being my 13th year anniversary as Editor in Chief. As always, I sincerely wish to thank again all the contributors to STH over the years, as well as Guest Editors for past issues, and of course the current and past Editorial team. There has been no major overhaul of the editorial team at the time of writing, although some adjustments will continue to occur over the coming years.

I also take this opportunity to once again thank the journal production team at Thieme Medical Publishers for their high production standards and for facilitating both the print and online issues of the journal.

This Editorial also represents the time that we reflect on our journal's impact factor, which for 2019 was 2.892, and thus it represents a significant decrease from our 2018 impact factor of 3.401. Although somewhat disappointed with this, I would also like to note that a significant decrease in impact factor was seen with most of the journals publishing in the thrombosis and hemostasis field (- Fig. 1). As typical for this yearly editorial, I also assessed the trends for self-citations, and this reflects positively for recent data (-Fig. 2). In any case, the impact factor is only one of the several markers of the journal "quality" that we should consider, and the limitations of any of the individual markers (including the impact factor) as a "quality" indicator, have previously been discussed. ${ }^{1,2}$

Like I also do annually, now, the highest cited (2017/2018 published) contributions ${ }^{3-34}$ from this journal are also listed in -Table $\mathbf{1}$ for the potential interest of the readership and contributing authors. These contributions identify those publications that are mostly contributing to the 2019 impact factor, and each were cited five or more times in the literature in 2019. For those interested, the current listing can be

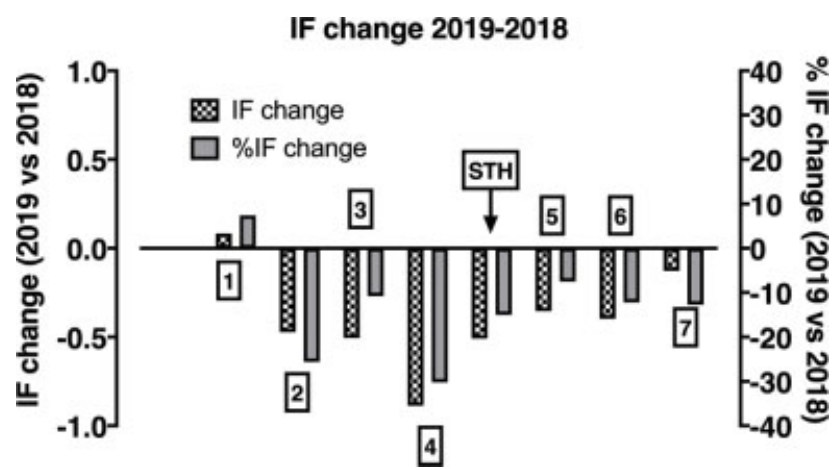

Fig. 1 More "falls" than "rises" in 2019 impact factors among eight journals publishing in thrombosis and hemostasis.

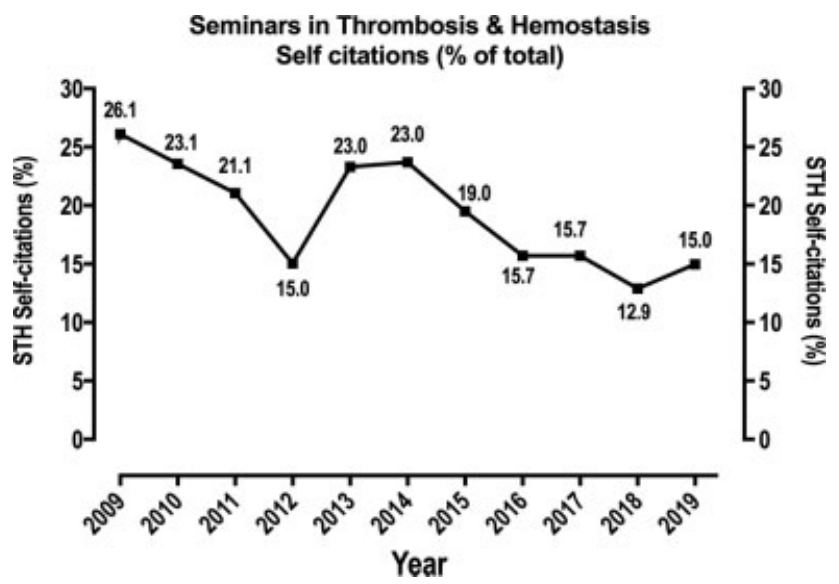

Fig. 2 Percentage of self-citations for Seminars in Thrombosis \& Hemostasis in recent years-aiming for less.
Address for correspondence Emmanuel J. Favaloro, PhD, FFSc (RCPA), Department of

Haematology, Centres for

Thrombosis and Haemostasis,

Institute of Clinical Pathology and Medical Research (ICPMR),

Westmead Hospital, Westmead, New South Wales 2145, Australia (e-mail: emmanuel.

favaloro@health.nsw.gov.au).
Issue Theme Editorial

Compilation IX; Guest Editors: Emmanuel J. Favaloro, PhD, FFSc (RCPA) and Giuseppe Lippi, MD. (c) 2021. Thieme. All rights reserved. Thieme Medical Publishers, Inc., 333 Seventh Avenue, 18th Floor, New York, NY 10001, USA
DOI https://doi.org/ 10.1055/s-0040-1721752. ISSN 0094-6176. 
Table 1 Top 2019-cited papers, as published in 2017/2018

\begin{tabular}{|c|c|}
\hline 1 & $\begin{array}{l}\text { Kitchen S, Tiefenbacher S, Gosselin R. Factor activity assays for monitoring extended half-life FVIII and factor IX } \\
\text { replacement therapies. Semin Thromb Hemost 2017;43(3):331-337 }\end{array}$ \\
\hline 2 & $\begin{array}{l}\text { Walsh M, Shreve J, Thomas S, et al. Fibrinolysis in trauma: “myth," "reality," or "something in between". Semin } \\
\text { Thromb Hemost 2017;43(2):200-212 }\end{array}$ \\
\hline 3 & $\begin{array}{l}\text { Flevaris P, Vaughan D. The role of plasminogen activator inhibitor type-1 in fibrosis. Semin Thromb Hemost } \\
\text { 2017;43(2):169-177 }\end{array}$ \\
\hline 4 & $\begin{array}{l}\text { Douxfils J, Gosselin RC. Laboratory assessment of direct oral anticoagulants. Semin Thromb Hemost 2017;43 } \\
\text { (3):277-290 }\end{array}$ \\
\hline 5 & $\begin{array}{l}\text { Bolliger D, Tanaka KA. Point-of-care coagulation testing in cardiac surgery. Semin Thromb Hemost 2017;43 } \\
\text { (4):386-396 }\end{array}$ \\
\hline 6 & $\begin{array}{l}\text { Gall LS, Brohi K, Davenport RA. Diagnosis and treatment of hyperfibrinolysis in trauma (a European perspective). } \\
\text { Semin Thromb Hemost 2017;43(2):224-234 }\end{array}$ \\
\hline 7 & $\begin{array}{l}\text { Draxler DF, Sashindranath M, Medcalf RL. Plasmin: a modulator of immune function. Semin Thromb Hemost } \\
2017 ; 43(2): 143-153\end{array}$ \\
\hline 8 & $\begin{array}{l}\text { Foley JH. Plasmin(ogen) at the nexus of fibrinolysis, inflammation, and complement. Semin Thromb Hemost } \\
2017 ; 43(2): 135-142\end{array}$ \\
\hline 9 & $\begin{array}{l}\text { Lippi G, Favaloro EJ. Venous and arterial thromboses: two sides of the same coin? Semin Thromb Hemost } \\
\text { 2018;44(3):239-248 }\end{array}$ \\
\hline 10 & Kim SJ, Davis RP, Jenne CN. Platelets as modulators of inflammation. Semin Thromb Hemost 2018;44(2):91-101 \\
\hline 11 & $\begin{array}{l}\text { Radin M, Cecchi I, Roccatello D, Meroni PL, Sciascia S. Prevalence and thrombotic risk assessment of anti- } \beta 2 \\
\text { glycoprotein I domain I antibodies: a systematic review. Semin Thromb Hemost 2018;44(5):466-474 }\end{array}$ \\
\hline 12 & $\begin{array}{l}\text { Russo V, Rago A, Papa AA, et al. Use of non-vitamin K antagonist oral anticoagulants in atrial fibrillation patients } \\
\text { with malignancy: clinical practice experience in a single institution and literature review. Semin Thromb Hemost } \\
\text { 2018;44(4):370-376 }\end{array}$ \\
\hline 13 & $\begin{array}{l}\text { Marlar RA, Clement B, Gausman J. Activated partial thromboplastin time monitoring of unfractionated heparin } \\
\text { therapy: issues and recommendations. Semin Thromb Hemost 2017;43(3):253-260 }\end{array}$ \\
\hline 14 & $\begin{array}{l}\text { Schreiber K, Breen K, Cohen H, et al. HYdroxychloroquine to Improve Pregnancy Outcome in Women with } \\
\text { AnTIphospholipid Antibodies (HYPATIA) protocol: a multinational randomized controlled trial of hydroxy- } \\
\text { chloroquine versus placebo in addition to standard treatment in pregnant women with antiphospholipid } \\
\text { syndrome or antibodies. Semin Thromb Hemost 2017;43(6):562-571 }\end{array}$ \\
\hline 15 & $\begin{array}{l}\text { Bikdeli B, Abou Ziki MD, Lip GYH. Pulmonary embolism and atrial fibrillation: two sides of the same coin? A } \\
\text { systematic review. Semin Thromb Hemost 2017;43(8):849-863 }\end{array}$ \\
\hline 16 & $\begin{array}{l}\text { Lippi G, Favaloro EJ, Sanchis-Gomar F. Sudden cardiac and noncardiac death in sports: epidemiology, causes, } \\
\text { pathogenesis, and prevention. Semin Thromb Hemost 2018;44(8):780-786 }\end{array}$ \\
\hline 17 & $\begin{array}{l}\text { Larsen JB, Hvas AM. Predictive value of whole blood and plasma coagulation tests for intra- and postoperative } \\
\text { bleeding risk: a systematic review. Semin Thromb Hemost 2017;43(7):772-805 }\end{array}$ \\
\hline 18 & $\begin{array}{l}\text { Sorrentino S, Giustino G, Moalem K, Indolfi C, Mehran R, Dangas GD. Antithrombotic treatment after } \\
\text { transcatheter heart valves implant. Semin Thromb Hemost 2018;44(1):38-45 }\end{array}$ \\
\hline 19 & $\begin{array}{l}\text { Alavi SER, Jalalvand M, Assadollahi V, Tabibian S, Dorgalaleh A. Intracranial hemorrhage: a devastating outcome } \\
\text { of congenital bleeding disorders-prevalence, diagnosis, and management, with a special focus on congenital } \\
\text { factor XIII deficiency. Semin Thromb Hemost 2018;44(3):267-275 }\end{array}$ \\
\hline 20 & Orme R, Judge HM, Storey RF. Monitoring antiplatelet therapy. Semin Thromb Hemost 2017;43(3):311-319 \\
\hline 21 & $\begin{array}{l}\text { Fredriksson L, Lawrence DA, Medcalf RL. tPA modulation of the blood-brain barrier: a unifying explanation for } \\
\text { the pleiotropic effects of tPA in the CNS. Semin Thromb Hemost } 2017 ; 43(2): 154-168\end{array}$ \\
\hline 22 & Vallier L, Cointe S, Lacroix R, et al. Microparticles and fibrinolysis. Semin Thromb Hemost 2017;43(2):129-134 \\
\hline 23 & $\begin{array}{l}\text { Croles FN, Borjas-Howard J, Nasserinejad K, Leebeek FWG, Meijer K. Risk of venous thrombosis in antithrombin } \\
\text { deficiency: a systematic review and Bayesian meta-analysis. Semin Thromb Hemost 2018;44(4):315-326 }\end{array}$ \\
\hline 24 & $\begin{array}{l}\text { Alatri A, Mazzolai L, Kucher N, et al. The modified Ottawa score and clinical events in hospitalized patients with } \\
\text { cancer-associated thrombosis from the Swiss VTE registry. Semin Thromb Hemost } 2017 ; 43(8): 871-876\end{array}$ \\
\hline 25 & $\begin{array}{l}\text { Kell DB, Pretorius E. To what extent are the terminal stages of sepsis, septic shock, systemic inflammatory } \\
\text { response syndrome, and multiple organ dysfunction syndrome actually driven by a prion/amyloid form of fibrin? } \\
\text { Semin Thromb Hemost } 2018 ; 44(3): 224-238\end{array}$ \\
\hline
\end{tabular}


Table 1 (Continued)

\begin{tabular}{|l|l|}
\hline 26 & $\begin{array}{l}\text { Stein P, Kaserer A, Spahn GH, Spahn DR. Point-of-care coagulation monitoring in trauma patients. Semin Thromb } \\
\text { Hemost 2017;43(4):367-374 }\end{array}$ \\
\hline 27 & Hunt BJ. Hemostasis at extremes of body weight. Semin Thromb Hemost 2018;44(7):632-639 \\
\hline 28 & $\begin{array}{l}\text { Dahlbäck B. Vitamin K-dependent protein S: beyond the protein C pathway. Semin Thromb Hemost 2018;44 } \\
(2): 176-184\end{array}$ \\
\hline 29 & $\begin{array}{l}\text { Turcato G, Cappellari M, Follador L, et al. Red blood cell distribution width is an independent predictor of } \\
\text { outcome in patients undergoing thrombolysis for ischemic stroke. Semin Thromb Hemost 2017;43(1):30-35 }\end{array}$ \\
\hline 30 & $\begin{array}{l}\text { Selle F, James C, Tuffigo M, et al. Clinical and laboratory findings in patients with } \delta \text {-storage pool disease: a case } \\
\text { series. Semin Thromb Hemost 2017;43(1):48-58 }\end{array}$ \\
\hline 31 & $\begin{array}{l}\text { Van Cott EM, Roberts AJ, Dager WE. Laboratory monitoring of parenteral direct thrombin inhibitors. Semin } \\
\text { Thromb Hemost 2017;43(3):270-276 }\end{array}$ \\
\hline 32 & $\begin{array}{l}\text { Russo V, Attena E, Mazzone C, et al. Nonvitamin K antagonist oral anticoagulants use in patients with atrial } \\
\text { fibrillation and bioprosthetic heart valves/prior surgical valve repair: a multicenter clinical practice experience. } \\
\text { Semin Thromb Hemost 2018;44(4):364-369 }\end{array}$ \\
\hline
\end{tabular}

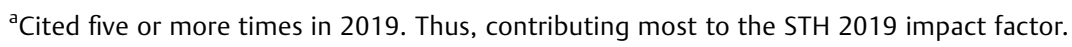

compared with the most recently published top downloaded article listings from Seminars in Thrombosis \&'Hemostasis, the basis of the Eberhard F. Mammen "Most Popular" awards. $^{35-39}$ Accordingly, I would like to thank all the contributors, guest editors, and the editorial team for bringing us the content that makes Seminars in Thrombosis $\mathcal{E}$ Hemostasis.

Several papers that I will highlight in particular: (a) the paper by the team of Kitchen, Tiefenbacher, and Gosselin ${ }^{3}$ was not only the most cited paper according to - Table 1, but was also awarded one of the 2019 Most Popular awards ${ }^{37}$; (b) the highly cited paper by Russo and colleagues ${ }^{14}$ was also awarded one of the 2020 Most Popular awards ${ }^{39}$; (c) the highly cited paper by Schreiber and colleagues ${ }^{16}$ was also awarded one of the 2020 Most Popular awards, ${ }^{39}$ as well as being authored by a recipient of a previous 2016 Young Investigator awardee; (d) the highly cited paper by Lippi and colleagues $^{18}$ was also awarded one of the 2020 Most Popular awards ${ }^{39}$; (e) the highly cited paper by Kell and Pretorius ${ }^{27}$ was also awarded one of the 2019 Most Popular awards. ${ }^{37}$

Several issues of the journal are also worthy to be highlighted as most of them contributed to the 2019 impact factor. The seven most highly contributing issues, ${ }^{40-46}$ both in terms of total and average impact factor contributions, were:
1. Fibrinolysis: Biochemistry, Clinical Aspects, and Therapeutic Potential. Guest Editors: Hau Kwaan, Ton Lisman, and Robert Medcalf. ${ }^{40}$

2. Laboratory Assessment of Hemostatic and Anticoagulant Therapy. Guest Editors: Dorothy M. Adcock, and Robert C. Gosselin. $^{41}$

3. Recent Advances in Thrombosis and Hemostasis-Part III. Guest Editor: Sam Schulman. ${ }^{42}$

4. Editorial Compilation V. Guest Editors: Emmanuel J. Favaloro and Giuseppe Lippi. ${ }^{43}$

5. Point-of-Care Testing in Acute Hemorrhagic and Thrombotic States. Guest Editor: Marcel Levi. ${ }^{44}$

6. Extrahemostatic Functions of Platelets and Coagulation Factors. Guest Editors: Roger Preston and Ton Lisman. ${ }^{45}$

7. Editorial Compilation III. Guest Editors: Emmanuel J. Favaloro and Giuseppe Lippi. ${ }^{46}$

Finally, a short note to confirm that we, like always, will continue to develop plans for the future content of this journal, and we are confident that Seminars would continue to bring its readers the high-quality journal that is expected of us. Currently confirmed topics for issues that we plan to publish over the next 12 or so months are listed in -Table 2. At the same time, we recognize the need to retain some

Table 2 Current planned topics for future issues of Seminars in Thrombosis \& Hemostasis include:

\begin{tabular}{|l|}
\hline • Editorial compilations (continuing series) \\
\hline - Recent advances in thrombosis and hemostasis (continuing series). \\
\hline - Maintaining hemostasis and preventing thrombosis in COVID-19 (continuing series). \\
\hline - Innovations in thrombosis and hemostasis part II: focus on tests and assays. \\
\hline - Hemostatic and nonhemostatic effects of heparan sulfate proteoglycans (HSPG). \\
\hline - Cardiovascular and thromboembolic diseases in oncology: novel aspects and revisited issues. \\
\hline - Personalized approaches to bleeding and thrombotic disorders. \\
\hline - Altered fibrinolysis: clinical impact and diagnostic challenges. \\
\hline
\end{tabular}

Abbreviation: COVID-19, coronavirus disease 2019. 
flexibility in our plans, and to potentially add additional material of current interest and controversy as the need arises. Notably, coronavirus disease 2019 (COVID-19) continues to create havoc for all of us, and this pandemic has led us to create a continuing series of issues specifically focused on thrombosis and hemostasis in COVID-19. Irrespective, we look forward to another interesting year of reading in 2021.

\section{Conflict of Interest}

None declared.

\section{References}

1 Favaloro EJ. The journal impact factor: don't expect its demise any time soon. Clin Chem Lab Med 2009;47(11):1319-1324

2 Favaloro EJ. Measuring the quality of journals and journal articles: the impact factor tells but a portion of the story. Semin Thromb Hemost 2008;34(01):7-25

3 Kitchen S, Tiefenbacher S, Gosselin R. Factor activity assays for monitoring extended half-life FVIII and factor IX replacement therapies. Semin Thromb Hemost 2017;43(03):331-337

4 Walsh M, Shreve J, Thomas S, et al. Fibrinolysis in trauma: "myth," "reality," or "something in between". Semin Thromb Hemost 2017;43(02):200-212

5 Flevaris P, Vaughan D. The role of plasminogen activator inhibitor type-1 in fibrosis. Semin Thromb Hemost 2017;43(02):169-177

6 Douxfils J, Gosselin RC. Laboratory assessment of direct oral anticoagulants. Semin Thromb Hemost 2017;43(03):277-290

7 Bolliger D, Tanaka KA. Point-of-care coagulation testing in cardiac surgery. Semin Thromb Hemost 2017;43(04):386-396

8 Gall LS, Brohi K, Davenport RA. Diagnosis and treatment of hyperfibrinolysis in trauma (a European perspective). Semin Thromb Hemost 2017;43(02):224-234

9 Draxler DF, Sashindranath M, Medcalf RL. Plasmin: a modulator of immune function. Semin Thromb Hemost 2017;43(02):143-153

10 Foley JH. Plasmin(ogen) at the nexus of fibrinolysis, inflammation, and complement. Semin Thromb Hemost 2017;43(02): 135-142

11 Lippi G, Favaloro EJ. Venous and arterial thromboses: two sides of the same coin? Semin Thromb Hemost 2018;44(03):239-248

12 Kim SJ, Davis RP, Jenne CN. Platelets as modulators of inflammation. Semin Thromb Hemost 2018;44(02):91-101

13 Radin M, Cecchi I, Roccatello D, Meroni PL, Sciascia S. Prevalence and thrombotic risk assessment of anti- $\beta 2$ glycoprotein I domain I antibodies: a systematic review. Semin Thromb Hemost 2018;44 (05):466-474

14 Russo V, Rago A, Papa AA, et al. Use of non-vitamin K antagonist oral anticoagulants in atrial fibrillation patients with malignancy: clinical practice experience in a single institution and literature review. Semin Thromb Hemost 2018;44(04):370-376

15 Marlar RA, Clement B, Gausman J. Activated partial thromboplastin time monitoring of unfractionated heparin therapy: issues and recommendations. Semin Thromb Hemost 2017;43 (03):253-260

16 Schreiber $\mathrm{K}$, Breen $\mathrm{K}$, Cohen $\mathrm{H}$, et al. HYdroxychloroquine to Improve Pregnancy Outcome in Women with AnTIphospholipid Antibodies (HYPATIA) protocol: a multinational randomized controlled trial of hydroxychloroquine versus placebo in addition to standard treatment in pregnant women with antiphospholipid syndrome or antibodies. Semin Thromb Hemost 2017;43(06): 562-571

17 Bikdeli B, Abou Ziki MD, Lip GYH. Pulmonary embolism and atrial fibrillation: two sides of the same coin? A systematic review. Semin Thromb Hemost 2017;43(08):849-863
18 Lippi G, Favaloro EJ, Sanchis-Gomar F. Sudden cardiac and noncardiac death in sports: epidemiology, causes, pathogenesis, and prevention. Semin Thromb Hemost 2018;44(08):780-786

19 Larsen JB, Hvas AM. Predictive value of whole blood and plasma coagulation tests for intra- and postoperative bleeding risk: a systematic review. Semin Thromb Hemost 2017;43(07):772-805

20 Sorrentino S, Giustino G, Moalem K, Indolfi C, Mehran R, Dangas GD. Antithrombotic treatment after transcatheter heart valves implant. Semin Thromb Hemost 2018;44(01):38-45

21 Alavi SER, Jalalvand M, Assadollahi V, Tabibian S, Dorgalaleh A. Intracranial hemorrhage: a devastating outcome of congenital bleeding disorders-prevalence, diagnosis, and management, with a special focus on congenital factor XIII deficiency. Semin Thromb Hemost 2018;44(03):267-275

22 Orme R, Judge HM, Storey RF. Monitoring antiplatelet therapy. Semin Thromb Hemost 2017;43(03):311-319

23 Fredriksson L, Lawrence DA, Medcalf RL. tPA modulation of the blood-brain barrier: a unifying explanation for the pleiotropic effects of tPA in the CNS. Semin Thromb Hemost 2017;43(02): 154-168

24 Vallier L, Cointe S, Lacroix R, et al. Microparticles and fibrinolysis. Semin Thromb Hemost 2017;43(02):129-134

25 Croles FN, Borjas-Howard J, Nasserinejad K, Leebeek FWG, Meijer K. Risk of venous thrombosis in antithrombin deficiency: a systematic review and Bayesian meta-analysis. Semin Thromb Hemost 2018;44(04):315-326

26 Alatri A, Mazzolai L, Kucher N, et al. The modified Ottawa score and clinical events in hospitalized patients with cancer-associated thrombosis from the Swiss VTE registry. Semin Thromb Hemost 2017;43(08):871-876

27 Kell DB, Pretorius E. To what extent are the terminal stages of sepsis, septic shock, systemic inflammatory response syndrome, and multiple organ dysfunction syndrome actually driven by a prion/amyloid form of fibrin? Semin Thromb Hemost 2018;44 (03):224-238

28 Stein P, Kaserer A, Spahn GH, Spahn DR. Point-of-care coagulation monitoring in trauma patients. Semin Thromb Hemost 2017;43 (04):367-374

29 Hunt BJ. Hemostasis at extremes of body weight. Semin Thromb Hemost 2018;44(07):632-639

30 Dahlbäck B. Vitamin K-dependent protein S: beyond the protein C pathway. Semin Thromb Hemost 2018;44(02):176-184

31 Turcato G, Cappellari M, Follador L, et al. Red blood cell distribution width is an independent predictor of outcome in patients undergoing thrombolysis for ischemic stroke. Semin Thromb Hemost 2017;43(01):30-35

32 Selle F, James C, Tuffigo M, et al. Clinical and laboratory findings in patients with $\delta$-storage pool disease: a case series. Semin Thromb Hemost 2017;43(01):48-58

33 Van Cott EM, Roberts AJ, Dager WE. Laboratory monitoring of parenteral direct thrombin inhibitors. Semin Thromb Hemost 2017;43(03):270-276

34 Russo V, Attena E, Mazzone C, et al. Nonvitamin K antagonist oral anticoagulants use in patients with atrial fibrillation and bioprosthetic heart valves/prior surgical valve repair: a multicenter clinical practice experience. Semin Thromb Hemost 2018;44(04): 364-369

35 Favaloro EJ. 2018 Eberhard F. Mammen Award Announcements: Part I-Most Popular Articles. Semin Thromb Hemost 2018;44 (03):185-192

36 Favaloro EJ. 2018 Eberhard F. Mammen Award Announcements: Part II-Young Investigator Awards. Semin Thromb Hemost 2019; 45(02):123-129

37 Favaloro EJ. 2019 Eberhard F. Mammen Award Announcements: Part I-Most Popular Articles. Semin Thromb Hemost 2019;45 (03):215-224 
38 Favaloro EJ. 2019 Eberhard F. Mammen Award Announcements: Part II-Young Investigator Awards. Semin Thromb Hemost 2020; 46(02):105-113

39 Favaloro EJ. 2020 Eberhard F. Mammen Award Announcements: Part I-Most Popular Articles. Semin Thromb Hemost 2020;46 (04):383-392

40 Kwaan H, Lisman T, Medcalf RL. Fibrinolysis: biochemistry, clinical aspects, and therapeutic potential. Semin Thromb Hemost 2017;43(02):113-114

41 Adcock DM, Gosselin RC. Laboratory assessment of hemostatic and anticoagulant therapy. Semin Thromb Hemost 2017;43(03):242-244
42 Schulman S. Recent advances in thrombosis and hemostasis-Part III. Semin Thromb Hemost 2018;44(04):312-314

43 Favaloro EJ, Lippi G. Editorial compilation V. Semin Thromb Hemost 2018;44(03):193-196

44 Levi M. Point-of-care testing in acute hemorrhagic and thrombotic states. Semin Thromb Hemost 2017;43(04):364-366

45 Preston RJS, Lisman T. Extrahemostatic functions of platelets and coagulation factors. Semin Thromb Hemost 2018;44(02): 89-90

46 Favaloro EJ, Lippi G. Editorial compilation III. Semin Thromb Hemost 2017;43(01):4-7 